\title{
Pharmacological characterization of the orexin/hypocretin receptor agonist Nag 26
}

\section{Rinne, Maiju K.}

2018-10-15

Rinne , M K, Leino , T O , Turku , A, Turunen , P M , Steynen , Y , Xhaard , H, Wallen , E A A \& Kukkonen , J P 2018 , ' Pharmacological characterization of the orexin/hypocretin receptor agonist Nag 26 ' , European Journal of Pharmacology , vol. 837 , pp. 137-144 . https://doi.org/10.1016/j.ejp

http://hdl.handle.net/10138/305214

https://doi.org/10.1016/j.ejphar.2018.09.003

cc_by_nc_nd

acceptedVersion

Downloaded from Helda, University of Helsinki institutional repository.

This is an electronic reprint of the original article.

This reprint may differ from the original in pagination and typographic detail.

Please cite the original version. 
Pharmacological characterization of the orexin/hypocretin receptor agonist Nag 26

Maiju K. Rinne ${ }^{\mathrm{a}, \mathrm{b}}$, Teppo O. Leino ${ }^{\mathrm{b}}$, Ainoleena Turku ${ }^{\mathrm{a}, \mathrm{b}}$, Pauli M. Turunen ${ }^{\mathrm{a}, \mathrm{c}}$, Yana Steynen ${ }^{\mathrm{b}}$, Henri Xhaard ${ }^{\mathrm{b}}$, Erik A. A. Wallén ${ }^{\mathrm{b}}$ and Jyrki P. Kukkonen ${ }^{\mathrm{a}, \mathrm{c}, *}$

${ }^{a}$ Biochemistry and Cell Biology, Department of Veterinary Biosciences, Faculty of Veterinary Medicine, University of Helsinki, Helsinki, Finland

${ }^{b}$ Drug Research Program, Division of Pharmaceutical Chemistry and Technology, Faculty of Pharmacy, University of Helsinki, Helsinki, Finland

${ }^{c}$ Physiology, Institute of Biomedicine, Faculty of Medicine, University of Helsinki, Helsinki, Finland

* Corresponding author: Jyrki P. Kukkonen, Physiology, Institute of Biomedicine, Faculty of Medicine, POB 63, FI-00014 University of Helsinki, Finland. Tel: +358-45 6503991 . Email: jyrki.kukkonen@helsinki.fi 


\section{Abstract}

One promising series of small-molecule orexin receptor agonists has been described, but the molecular pharmacological properties, i.e. ability and potency to activate the different orexin receptor-regulated signal pathways have not been reported for any of these ligands. We have thus here assessed these properties for the most potent ligand of the series, 4'-methoxy- $N, N$ dimethyl-3'-[N-(3-\{[2-(3-methylbenzamido)ethyl]amino $\}$ phenyl sulfamoyl]-(1,1'-biphenyl)3-carboxamide (Nag 26). Chinese hamster ovary-K1 cells expressing human orexin receptor subtypes $\mathrm{OX}_{1}$ and $\mathrm{OX}_{2}$ were used. $\mathrm{Ca}^{2+}$ elevation and cell viability and death were assessed by fluorescent methods, the extracellular signal-regulated kinase pathway by a luminescent Elk-1 reporter assay, and phospholipase $\mathrm{C}$ and adenylyl cyclase activities by radioactive methods. The data suggest that for the $\mathrm{G}_{\mathrm{q}}$-dependent responses, $\mathrm{Ca}^{2+}$, phospholipase $\mathrm{C}$ and Elk-1, Nag 26 is a full agonist for both receptors, though of much lower potency. However, saturation was not always reached for $\mathrm{OX}_{1}$, partially due to Nag 26's low solubility and partially because the response decreased at high concentrations. The latter occurs in the same range as some reduction of cell viability, which is independent of orexin receptors. Based on the $\mathrm{EC}_{50}$, Nag 26 was $\mathrm{OX}_{2}$-selective by 20-200 fold in different assays, with some indication of biased agonism (as compared to orexin-A). Nag 26 is a potent orexin receptor agonist with a largely similar pharmacological profile as orexin-A. However, its weaker potency (low-mid micromolar) and low water solubility as well as the non-specific effect in the mid-micromolar range may limit its usefulness under physiological conditions.

Keywords: orexin; calcium; phospholipase C; cAMP; cell death; ERK 


\section{Introduction}

Orexin-A and -B are hypothalamic neuropeptides that have been most strongly associated with regulation of sleep and wakefulness (reviewed in Li et al., 2017; Scammell et al., 2017). This is most clearly seen in narcolepsy; death of orexinergic neurons is thought to lie behind human narcolepsy (Nishino et al., 2000), and narcoleptic phenotype is seen in animals upon genetic destruction of orexinergic neurons, orexin peptides or orexin receptors, or toxic destruction of orexin target neurons (Chemelli et al., 1999; Lin et al., 1999; Hara et al., 2001; Gerashchenko et al., 2001; Willie et al., 2003). The orexin system has also been associated with other central physiological and pathophysiological functions, such as metabolic regulation, feeding, stress response, addiction and pain gating (reviewed in Kukkonen, 2013; Baimel et al., 2015), and orexin receptor polymorphisms have been and are investigated with respect to additional indications such as anxiety and depression (reviewed in Thompson et al., 2014). It can thus be assumed that both orexin receptor antagonists and agonists might be useful in different types of disorders. Orexin receptor antagonist discovery is currently mainly focusing on the development of hypnotics (reviewed in Roecker et al., 2016); one such drug, suvorexant, is already on the market in the US and Japan. Orexin receptor agonists, on the other hand, would find an obvious use in narcolepsy - a concept that has been proven in rodents (Mieda et al., 2004; Kantor et al., 2013; Irukayama-Tomobe et al., 2017) - as well as likely in other disorders of increased sleep and reduced vigilance. Other apparent, though thus far less substantiated, uses of the agonists would be in some metabolic disorders and some cancers; orexin receptor stimulation can also stimulate programmed cell 
death of some cancer cells (Rouet-Benzineb et al., 2004; Ammoun et al., 2006; Voisin et al., 2006; Voisin et al., 2011).

While orexin antagonist development has been very active and successful, little has happened on the agonist side. Only one potent series of small molecular weight orexin receptor agonists has been described (Nagahara et al., 2015); the other reported agonists appear to have low potency and possible low selectivity (see, e.g. Turku et al., 2016; Turku et al., 2017). The pharmacological properties of even the promising series reported in (Nagahara et al., 2015) are barely known. We thus decided to characterized the most potent ligand of the series, 4'-methoxy- $N, N$-dimethyl-3'-[N-(3-\{[2-(3-methylbenzamido)ethyl]amino $\}$ phenyl) sulfamoyl]-(1,1'-biphenyl)-3-carboxamide (compound 26; here referred as Nag 26), in the current study. The ligand was synthesized and its activity and potency with respect to a number of different responses, involving the three classical G-protein pathways, was assessed for both human orexin receptor subtypes expressed in Chinese hamster ovary K1 (CHO) cells.

\section{Materials and methods}

\subsection{Materials}

Human orexin-A was from NeoMPS (Strasbourg, France), 2-(1-[3-dimethylaminopropyl]$1 H$-indol-3-yl)-3-(1H-indol-3-yl)-maleimide (GF109203X), $N$-biphenyl-2-yl-1- $\{[(1-m e t h y l-$ 1H-benzimidazol-2-yl)sulfanyl]acetyl $\}$-L-prolinamide (TCS 1102), (2Z,3Z)-bis(\{amino[(2aminophenyl)sulfanyl]methylidene \}) butanedinitrile (U0126), thapsigargin and pertussis toxin from Tocris Bioscience (Bristol, UK), and cholera toxin, forskolin, staurosporin and 3isobutyl-1-methylxanthine from Sigma-Aldrich. Hoechst 33342 [2'-(4-ethoxyphenyl)-5-(4- 
methyl-1-piperazinyl)-1H,1'H-2,5'-bibenzimidazole; here abbreviated as Hoechst] was from Molecular Probes/Life Technologies (Carlsbad, CA, USA), PrestoBlue and 4-[(3-methyl-1,3benzoxazol-2(3H)-ylidene)methyl]-1-[3-(trimethylammonio)propyl] quinolinium diiodide (YO-PRO-1 iodide, here abbreviated as YO-PRO) from Thermo Fisher Scientific Finland (Espoo, Finland) and L-threonine,(3R)- $N$-acetyl-3-hydroxy-L-leucyl-(a $R)$-ahydroxybenzenepropanoyl-2,3-idehydro- $N$-methylalanyl-L-alanyl- $N$-methyl-L-alanyl-(3R)-3[[(2S,3R)-3-hydroxy-4-methyl-1-oxo-2-[(1-oxopropyl)amino]pentyl]oxy]-L-leucyl- $N, O$ dimethyl-,(7 $\rightarrow 1$ )-lactone (9CI) (UBO-QIC a.k.a. FR900359) from the Institute of Pharmaceutical Biology, University of Bonn (Bonn, Germany; http://www.pharmbio.unibonn.de/signaltransduktion/quote). Myo-[2- $\left.{ }^{3} \mathrm{H}\right]$ inositol (PT6-271) and $\left[2,8-{ }^{3} \mathrm{H}\right]$ adenine were from PerkinElmer Life and Analytical Sciences (Waltham, MA, USA).

Nag 26 was synthesized applying the method by Nagahara et al. (2015). The identity of compound was verified by high-resolution mass spectrometry and ${ }^{1} \mathrm{H}$ and ${ }^{13} \mathrm{C}$ NMR spectroscopy; these data are in accordance with the literature. Purity was $>95 \%$ as assessed by ultra performance liquid chromatography. Details of the analysis are as follows: White, amorphous solid. ${ }^{1} \mathrm{H}$ NMR (400 MHz, $\left.\mathrm{CD}_{3} \mathrm{CN}\right) \delta 8.02(\mathrm{~d}, J=2.4 \mathrm{~Hz}, 1 \mathrm{H}), 7.80-7.78(\mathrm{~m}$, 2H), 7.61-7.57 (m, 2H), 7.54-7.51 (m, 2H), $7.41(\mathrm{t}, J=7.8 \mathrm{~Hz}, 1 \mathrm{H}), 7.34-7.27(\mathrm{~m}, 3 \mathrm{H}), 7.23$ $(\mathrm{t}, J=4.8 \mathrm{~Hz}, 1 \mathrm{H}), 7.17(\mathrm{~d}, J=8.4 \mathrm{~Hz}, 1 \mathrm{H}), 6.91(\mathrm{t}, J=8.0 \mathrm{~Hz}, 1 \mathrm{H}), 6.43(\mathrm{t}, J=2.2 \mathrm{~Hz}, 1 \mathrm{H})$, 6.36-6.33 (m, 1H), 6.29-6.26 (m, 1H), $4.71(\mathrm{~s}, 1 \mathrm{H}), 4.02(\mathrm{~s}, 3 \mathrm{H}), 3.48(\mathrm{q}, J=6.0 \mathrm{~Hz}, 2 \mathrm{H})$, 3.16-3.15 (m, 2H), $3.02(\mathrm{~s}, 3 \mathrm{H}), 2.91(\mathrm{~s}, 3 \mathrm{H}), 2.35(\mathrm{~s}, 3 \mathrm{H}) .{ }^{13} \mathrm{C} \mathrm{NMR}\left(101 \mathrm{MHz}, \mathrm{CD}_{3} \mathrm{CN}\right) \delta$ $171.7,168.6,157.1,150.4,139.9,139.4,139.3,138.6,135.4,134.3,133.2,133.0,130.7$, $130.0,130.0,129.3,128.7,128.4,127.6,126.9,125.9,125.1,114.1,110.3,109.6,104.5$, 57.2, 44.0, 39.8, 39.7, 35.4, 21.4. High-resolution mass spectrometry (electrospray ionization 
quadrupole time-of-flight mass spectrometry) $m / z$ : Calculated for $[\mathrm{M}+\mathrm{H}]^{+} \mathrm{C}_{32} \mathrm{H}_{35} \mathrm{~N}_{4} \mathrm{O}_{5} \mathrm{~S}$ 587.2328; Found 587.2325.

\subsection{Cell culture and media}

CHO-hOX 1 and -hOX 2 cells (Lund et al., 2000; Ammoun et al., 2003) as well as ctrl CHO$\mathrm{K} 1$ cells (not expressing orexin receptors; ctrl CHO cells) were cultured in Ham's F12 medium (Gibco/Life Technologies, Paisley, UK) + supplements on plastic cell culture dishes (56 $\mathrm{cm}^{2}$ bottom area; Greiner Bio-One GmbH, Frickenhausen, Germany) as described in (Jäntti et al., 2012). Different types of multi-well plates were used for the assays: black, clearbottom half-area Cellstar $\mu$ Clear 96-well cell culture plates (Greiner Bio-One GmbH) for $\mathrm{Ca}^{2+}$ measurements; black, clear-bottom Cellstar $\mu$ Clear 96-well cell culture plates (Greiner) for cell death assays; and clear Cellstar 48- or 96-well cell culture plates (Greiner) for phospholipase $\mathrm{C}$ and adenylyl cyclase assays. All multi-well plates were coated with polyethyleneimine ( $25 \mu \mathrm{g} / \mathrm{ml}$ for 1 hour at $37^{\circ} \mathrm{C}$; Sigma-Aldrich, St. Louis, MO, USA). Cells were for the adenylyl cyclase experiments pretreated for $20 \mathrm{~h}$ with cholera toxin $(1000 \mathrm{ng} / \mathrm{ml})$ or for $36 \mathrm{~h}$ with pertussis toxin $(300 \mathrm{ng} / \mathrm{ml})$.

Hepes-buffered medium (HBM) was used as the basic experimental medium. It was composed of $137 \mathrm{mM} \mathrm{NaCl}, 5 \mathrm{mM} \mathrm{KCl}, 1.2 \mathrm{mM} \mathrm{MgCl} 2,0.44 \mathrm{mM} \mathrm{KH}_{2} \mathrm{PO}_{4}, 4.2 \mathrm{mM}$ $\mathrm{NaHCO}_{3}, 1 \mathrm{mM} \mathrm{CaCl}, 10 \mathrm{mM}$ glucose, $20 \mathrm{mM}$ HEPES, and adjusted to $\mathrm{pH} 7.4$ with $\mathrm{NaOH}$.

\section{3. $\mathrm{Ca}^{2+}$ elevation}


$\mathrm{Ca}^{2+}$ elevations were measured as described before (Turku et al., 2017). Briefly, $1.5 \times 10^{4}$ cells per well were plated on black, clear bottom half-area 96-well plates. Twenty-four hours later, cell culture medium was removed and the cells were exposed to the loading solution composed of FLIPR Calcium 4 Assay Kit (Molecular Devices, Sunnyvale, CA, USA) dissolved in and diluted with $\mathrm{HBM}+1 \mathrm{mM}$ probenecid, for $60 \mathrm{~min}$ at $37^{\circ} \mathrm{C}$. Intracellular $\mathrm{Ca}^{2+}$ levels were measured as fluorescence changes (excitation at $485 \mathrm{~nm}$, emission at 525 $\mathrm{nm}$ ) at $37^{\circ} \mathrm{C}$ using a FlexStation 3 fluorescence plate reader (Molecular Devices). A recording was made approximately every $1.3 \mathrm{~s}$. Each well was measured for $150 \mathrm{~s}$ with $30 \mathrm{~s}$ of baseline before stimulation (see Fig. $1 \mathrm{AB}$ ). Antagonists were manually added in the wells during the probe incubation (30 min before the measurement).

\subsection{Phospholipase C activity}

Phospholipase C activity was measured as described before (Turku et al., 2017). Briefly, $1.1 \times 10^{4}$ or $2.4 \times 10^{4}$ cells per well were plated on clear 96 - or 48 -well plates, respectively. Twenty-four hours later, they were labelled with $3 \mu \mathrm{Ci} / \mathrm{ml}\left[{ }^{3} \mathrm{H}\right]$ inositol for $20 \mathrm{~h}$. The medium was removed, and the cells were incubated in $\mathrm{HBM}$ supplemented with $10 \mathrm{mM} \mathrm{LiCl}$ for 30 $\min$ at $37^{\circ} \mathrm{C}$; also the possible inhibitors, TCS 1102 and L-threonine, $(3 R)-N$-acetyl-3hydroxy-L-leucyl-(a $R$ )-a-hydroxybenzenepropanoyl-2,3-idehydro- $N$-methylalanyl-L-alanyl$N$-methyl-L-alanyl-(3R)-3-[[(2S,3R)-3-hydroxy-4-methyl-1-oxo-2-[(1-oxopropyl)amino] pentyl]oxy]-L-leucyl-N,O-dimethyl-, $(7 \rightarrow 1)$-lactone (9CI) (UBO-QIC), were included in this incubation. They were then stimulated with orexin-A or Nag 26 for 30 min, after which the medium was rapidly removed and the reactions stopped with ice-cold perchloric acid and freezing. The samples were thawed and neutralized, and the insoluble fragments spun down. The total inositol phosphate fraction of the supernatants was isolated by anion-exchange 
chromatography, and the radioactivity determined by scintillation counting (HiSafe 3 scintillation cocktail and Wallac 1415 liquid scintillation counter; PerkinElmer).

\subsection{Adenylyl cyclase activity}

Adenylyl cyclase activity was measured as described before (Turku et al., 2017). Briefly, $2.4 \times 10^{4}$ (cholera toxin-treated) or $3.0 \times 10^{4}$ (pertussis toxin-treated) cells per well were plated on clear 48-well plates. The cells were treated with pertussis toxin after $8 \mathrm{~h}$ or with cholera toxin after $24 \mathrm{~h}$. Forty-eight hours after the plating, the cells were labelled with $5 \mu \mathrm{Ci} / \mathrm{ml}$ $\left[{ }^{3} \mathrm{H}\right]$ adenine for $2 \mathrm{~h}$. After the labelling, the cells were washed once with phosphate-buffered saline. HBM, supplemented with $500 \mu \mathrm{M}$ 3-isobutyl-1-methylxanthine (a cyclic nucleotide phosphodiesterase inhibitor) and $3 \mu \mathrm{M}$ GF109203X (a protein kinase C inhibitor), was added to the cells. The cells were incubated for $30 \mathrm{~min}$ at $37{ }^{\circ} \mathrm{C}$ before adding the stimulants (forskolin \pm orexin-A or Nag 26). After an additional 10-min incubation at $37^{\circ} \mathrm{C}$, the medium was discarded and the reactions terminated with ice-cold perchloric acid and rapid freezing. After thawing, the insoluble fragments were spun down, and the $\left[{ }^{3} \mathrm{H}\right] \mathrm{ATP}+$ $\left[{ }^{3} \mathrm{H}\right] \mathrm{ADP}$ and $\left[{ }^{3} \mathrm{H}\right] \mathrm{cAMP}$ fractions were isolated by sequential Dowex-alumina chromatography. Radioactivity of the fractions was determined with scintillation counting as above. The conversion of $\left[{ }^{3} \mathrm{H}\right]$ ATP to $\left[{ }^{3} \mathrm{H}\right] \mathrm{cAMP}$ was calculated as percentage of the total eluted $\left[{ }^{3} \mathrm{H}\right] \mathrm{ATP}+\left[{ }^{3} \mathrm{H}\right] \mathrm{ADP}$.

\subsection{Plasmids, transfection and the Elk-1 activity luciferase assay}

The plasmid pSG-GalElk-1 (fusion of the dimerization domain of the transcription factor Elk1 and the DNA-binding domain of the yeast transcription factor Gal4) (Kortenjann et al., 1994) was a kind gift from Dr. Peter E. Shaw (Queen's Medical Centre, Nottingham, UK), 
pGL3 G5 E4 $\Delta 38$ (5× Gal4 binding site controlling firefly luciferase expression) (Kamano et al., 1995) from Dr. Karl-Heinz Klempnauer (Westfälische-Wilhelms-Universität Münster, Germany) via Drs. Peter E. Shaw and Michael J. Courtney (Turku Centre for Biotechnology, Turku, Finland), and pRL-TK (Renilla luciferase under herpes simplex virus thymidine kinase promoter) from Promega (Madison, WI, USA); empty pUC18 plasmid was used to make the DNA amount optimal for transfection.

Transient transfection was used for the Elk-1 activity assay in $\mathrm{CHO}-\mathrm{hOX}_{1}$ and $-\mathrm{hOX}_{2}$ cells. Cells on 96-well plates were grown to $40 \%$ confluence and transfected in Ham's F-12 with $0.312 \mathrm{mg} / \mathrm{cm}^{2}$ DNA and $0.74 \mathrm{ml} / \mathrm{cm}^{2}$ FugeneHD (Roche, Mannheim, Germany). The optimized transfection conditions used for DNA were $0.6 \%$ (w/v) pSG-GalElk-1, 50\% pGL3 G5 E4 D38, 10.8\% pRL-TK, and 38.6\% of pUC18. Five hours after transfection the cells were washed and changed to serum-free medium to serum-starve the cells overnight. The following day, the cells were stimulated in fresh serum-free medium. The inhibitors (U0126, TCS 1102, UBO-QIC) were added to the cells together with orexin -A or Nag 26. After 5 hours of stimulation, the cells were lysed, collected into Eppendorf tubes and frozen. The assay was then continued according to the instructions of the manufacturer of the assay kit (Dual-Luciferase Reporter Assay system; Promega). Luminescence was measured with GloMax 20/20 luminometer (Promega). The Elk-1-specific signal (firefly luciferase) was normalized to the Renilla luciferase signal in each sample; however, since the orexin receptor stimulation increased even the Renilla luciferase expression (or activity; maximally twofold), all the results were adjusted to the average of the Renilla luciferase signals not to underestimate the stimulation magnitude.

2.7. Cell viability and death 
Cells were seeded on black, clear bottom 96 -well plates $4 \times 10^{3}$ per well. The cells were cultured overnight and treated the following day. Staining and quantitation was done $72 \mathrm{~h}$ later. The cells were stained with Hoechst $(10 \mu \mathrm{M})$, YO-PRO $(0.1 \mu \mathrm{M})$ and PrestoBlue ${ }^{\circledR}(0.1$ $\mu \mathrm{M})$ for $25 \mathrm{~min}$ at $37^{\circ} \mathrm{C}$. Hoechst stains all nuclei, and is in this assay a measure of total cell number. YO-PRO has been suggested to can only stain apoptotic and not necrotic cells, but our experience is that it rather works as propidium iodide, i.e. staining cells with already some membrane damage, though maybe a bit earlier than propidium iodide (unpublished). Essentially, it is a measure necrosis (primary or secondary). PrestoBlue contains essentially non-fluorescent resazurin that is reduced in live mitochondria to red fluorescent resorufin, and is thus a measure of cell viability. Fluorescence was read using FlexStation 3 at the wavelengths $352 \mathrm{~nm} / 455 \mathrm{~nm}$ (Hoechst), $480 \mathrm{~nm} / 515 \mathrm{~nm}$ (YO-PRO) and 550/590 nm (PrestoBlue).

\subsection{Data analysis}

Each experiment was performed in triplicate (adenylyl cyclase activity, Elk-1 luciferase assay) or quadruplicate $\left(\mathrm{Ca}^{2+}\right.$, phospholipase $\mathrm{C}$ activity, cell viability/death). All the data presented are summarized from several batches of cells (number given by $n$ ) unless specifically indicated to be data from a single experiment (Fig. 1AB); the averaged data are presented as mean \pm S.E.M. Student's non-paired (Fig. 6AC) or paired (Fig. 6A) two-tailed $t$ test with Bonferroni correction for multiple comparisons was used for all statistical comparisons. Significances are as follows: ns (not significant; $\mathrm{P}>0.05),{ }^{*} \mathrm{P}<0.05,{ }^{*} * \mathrm{P}<$ $0.01, * * * \mathrm{P}<0.001$; NS and the symbol $\uparrow$ are used in the same way for the second 
comparison. Microsoft Excel was used for all data visualizations and analyses including nonlinear curve-fitting according to the equations

response $=$ basal $+\frac{[\text { ligand }]^{\mathrm{n}_{\mathrm{h}}} \times \text { response }_{\max }}{[\text { ligand }]^{\mathrm{n}_{\mathrm{h}}}+\mathrm{EC}_{50}{ }^{\mathrm{n}_{\mathrm{h}}}}$

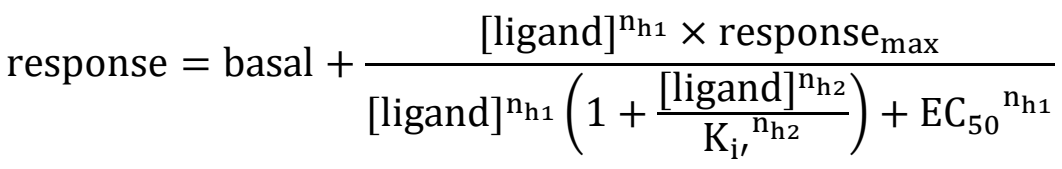

. $\mathrm{n}_{\mathrm{h}}$ is the co-operativity (Hill) coefficient. Eq. 1 was used for fitting of all concentrationresponse data (Fig. 6; Table S1, in reverse version for Fig. S1). Eq. 2 was used only for the alternative curve-fitting of the Elk-1 data (Elk-1 alt.) for Nag 26 (Fig. 7; Table S1). In this fitting, the inhibitory component clearly seen to cause the bell-shape of the Nag 26 concentration-response curve of $\mathrm{OX}_{2}$ (Figs. 3 and 7) was assumed to be the same for both $\mathrm{OX}_{1}$ and $\mathrm{OX}_{2}$ and fitted according to the equation for uncompetitive inhibition. The maximum stimulatory responses were also assumed to be equal for both receptor subtypes (see Fig. 7). Please observe that this is does not aim at a mechanistic explanation of the apparent inhibition but simply represents a way of including the inhibition in the equation. Other ways of modelling the inhibition gave similar results.

\section{Results}

Both orexin- $\mathrm{A}$ and $\mathrm{Nag} 26$ caused robust $\mathrm{Ca}^{2+}$ response in orexin receptor-expressing $\mathrm{CHO}$ cells (Fig. 1AB). The maximum response was equal for both ligands (Figs. 1CD and 6; Table 
S1), while orexin-A was clearly more potent (Figs. 1CD and 6; Table S1). Nag 26 showed some selectivity; when normalized to orexin-A, it had 17.6 \pm 5.4 -fold $(n=7)$ higher potency for $\mathrm{OX}_{2}$ than for $\mathrm{OX}_{1}$ (Fig. 6). The response to Nag 26 could be concentration-dependently inhibited by TCS 1102 (Fig. S1), and only high Nag 26 concentrations produced a minute response in the ctrl $\mathrm{CHO}$ cells not expressing orexin receptors (Fig. S2). Nag 26 response in orexin receptor-expressing CHO cells was nearly fully inhibited by $1 \mu \mathrm{M}$ of the $\mathrm{G}_{\mathrm{q} / 11}$ inhibitor UBO-QIC (Fig. S3).

Phospholipase $\mathrm{C}$ activation is one of the calcium-elevating mechanisms of orexin

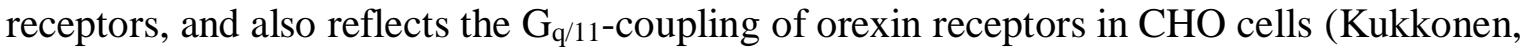
2016a). However, the phospholipase $\mathrm{C}$ response is not as easily saturated as the $\mathrm{Ca}^{2+}$ response, and thus may better indicate the actual efficacies of the ligands. As reported earlier (Kukkonen, 2016b; Turku et al., 2017), orexin-A stimulation robustly activated phospholipase C (Fig. 2AB; Table S1). Nag 26 was also a strong activator, but did not quite reach the level of orexin-A (at least not for $\mathrm{OX}_{1}$ ) (Figs. 2AB and 6; Table S1). Nag 26, again, indicated selectivity for $\mathrm{OX}_{2}$ over $\mathrm{OX}_{1}$ based on the potency $(28.8 \pm 2.7$ fold, $n=6$; normalized to orexin-A), and it also showed slightly higher maximum response for $\mathrm{OX}_{2}$ (Figs. 2AB and 6; Table S1). Even saturating Nag 26 responses were inhibited by $10 \mu \mathrm{M}$ TCS 1102 as well as by $1 \mu \mathrm{M}$ UBO-QIC (Fig. S3).

Both orexin-A and Nag 26 caused significant responses in the Elk-1 luciferase reporter assay (Fig. 3). Elk-1 is activated by extracellular signal-regulated kinase 1/2 (ERK1/2) but also by other mitogen-activated protein kinases (MAPKs); the involvement of ERK in the Nag 26 response was verified by the fact it was inhibited by $3 \mu \mathrm{M}$ U0126, an inhibitor of the upstream activator of ERK1/2, MAPK/ERK kinase 1 (Fig. S3), as previously shown for orexin-A (Jäntti et al., 2013). The response was also specific to orexin receptors and 
dependent on the $\mathrm{G}_{\mathrm{q}}$ pathway, as it was fully inhibited by $10 \mu \mathrm{M}$ TCS 1102 and $1 \mu \mathrm{M}$ UBOQIC, respectively (Fig. S3). Interestingly, the concentration-response curves for Nag 26, especially for $\mathrm{OX}_{2}$, were bell-shaped, i.e. the response started decreasing after $10 \mu \mathrm{M}$ (Fig. $3)$.

Adenylyl cyclase has been suggested to be regulated by orexin receptors via at least three different pathways in $\mathrm{CHO}$ cells, i.e. inhibition via $\mathrm{G}_{\mathrm{i}}$ and stimulation via $\mathrm{G}_{\mathrm{s}}$ and protein kinase C (Holmqvist et al., 2005; Kukkonen, 2016a; Kukkonen, 2016b). The analysis is difficult, as there are no highly efficient inhibitors for the $G_{i}$ and $G_{s}$ pathways and possibly also because there are other components, as suggested recently (Kukkonen, 2016a). In cells treated with pertussis toxin and GF1092203X, in which the $\mathrm{G}_{\mathrm{i}}$ and protein kinase $\mathrm{C}$ responses should be eliminated, both orexin-A and Nag 26 stimulated adenylyl cyclase activity (Fig. 4AB; Table S1), though the efficacy of Nag 26 was rather low. Interestingly, Nag 26 produced an apparently equal stimulation in both $\mathrm{OX}_{1}$ - and $\mathrm{OX}_{2}$-expressing cells, while orexin-A was a much better stimulant of adenylyl cyclase via $\mathrm{OX}_{1}$ receptors than $\mathrm{Nag} 26$ (Fig. 4AB). In cells treated with cholera toxin and GF109203X, the protein kinase C response is eliminated and adenylyl cyclase saturated with $\mathrm{G} \alpha_{\mathrm{s}}$, and thus inhibition of adenylyl cyclase activity can be monitored (Holmqvist et al., 2005; Kukkonen, 2016a; Kukkonen, 2016b). Both orexin-A and Nag 26 inhibited the adenylyl cyclase activity (Fig. 4CD), though the response to orexin-A was lower than previously reported (Kukkonen, 2016b). The maximum response to Nag 26 was even lower than that to orexin-A (Fig. 4CD), and the determination of the $\mathrm{EC}_{50}$ value was not reliable. Both adenylyl cyclase stimulation and inhibition by Nag 26 were inhibited by TCS 1102 (Fig. S3).

Orexin receptor stimulation has been reported to reduce the growth and induce programmed cell death in $\mathrm{CHO}$ cells as well as other cell types (Introduction), possibly via 
the $\mathrm{G}_{\mathrm{q}}$ pathway. We have also recently reported that the small molecule orexin receptor agonist, Yan 7874, induces orexin receptor-independent necrotic cell death (Turku et al., 2017). We thus wanted to assess the ability of Nag 26 to induce cell death in our orexin receptor-expressing $\mathrm{CHO}$ cells. In the current study, $100 \mathrm{nM}$ orexin-A caused a rather weak reduction in total (Hoechst; Fig. 5A) and viable (PrestoBlue/Hoechst; Fig. 5B) cell number and increase in cell death in $\mathrm{OX}_{1}$ receptor expressing (YoPro/Hoechst; Fig. 5C) cells, and the response was even weaker in $\mathrm{OX}_{2}$ receptor-expressing cells (Fig. 5A-C). Ctrl CHO cells not expressing orexin receptors did not respond to $100 \mathrm{nM}$ orexin-A (Fig. 5A-C). Nag 26 at low concentrations gave a small increase in the total cell number but at the same time a reduction in the cell viability (Fig. 5D-F). At higher concentrations, Nag 26 led to a decrease in the total (Hoechst) and viable (PrestoBlue/Hoechst) cell numbers and an increase in cell death (YoPro/Hoechst), but similar responses were also partially seen in the control cells (Fig. 5DF), suggesting that it was not fully orexin receptor-specific. The orexin receptor-independent cell death-promoting compounds staurosporin and thapsigargin, used as a control, caused a much stronger reduction in cell number and increase in cell death (Fig. S4). 


\section{Discussion}

In the current study, we assess the properties of Nag 26, one of the hit molecules of a promising series of small molecule orexin receptor agonists (Nagahara et al., 2015). The other hit molecule is compound 30/31 a.k.a. YNT-185 which is more water-soluble than Nag 26 but also slightly less potent in the $\mathrm{Ca}^{2+}$ elevation assay than Nag 26 (Nagahara et al., 2015; Irukayama-Tomobe et al., 2017). It is somewhat unclear, which compound - if any of these two - is more interesting for development of orexin receptor agonists; YNT-185 is apparently not lipid-soluble enough to enter the brain (Irukayama-Tomobe et al., 2017) while the higher lipid solubility of Nag 26 (Nagahara et al., 2015) might make it better suited in this respect though this has not been tested thus far.

As concerns the $\mathrm{Ca}^{2+}$ elevation, we can largely verify the results of the previous study (Nagahara et al., 2015), though the selectivity of Nag 26 for $\mathrm{OX}_{2}$ is about 20-fold, which is somewhat lower than the previously reported 70 -fold. It should be noted that the potencies in cells lines expressing $\mathrm{OX}_{1}$ and $\mathrm{OX}_{2}$ receptors at different levels cannot be directly compared, but the selectivity should be analyzed with respect to a "standard" ligand, e.g. orexin-A, as done here. In such comparison of the values in (Nagahara et al., 2015), the selectivity is reduced from 70- to 47 -fold. Remarkably, Nag 26 is reported to be only 23 -fold less potent than orexin-A for $\mathrm{OX}_{2}$ receptors in (Nagahara et al., 2015), while we consequently found it to be about 100 -fold less potent with respect to both $\mathrm{Ca}^{2+}$ and phospholipase $\mathrm{C}$ responses (Table S1). For the phospholipase $\mathrm{C}$ activation, which like $\mathrm{Ca}^{2+}$ elevation relies on $\mathrm{G}_{\mathrm{q}}$, the potencies of both orexin-A and Nag 26 were lower than for $\mathrm{Ca}^{2+}$ elevation. This is expected as $\mathrm{Ca}^{2+}$ elevation is usually strongly amplified/blunted (i.e. has a larger receptor reserve), leading to a left-shift of the concentration-response curve. The difference in potency between orexin-A 
and Nag 26 was nevertheless nearly the same as for the $\mathrm{Ca}^{2+}$ response, as expected, as also is the selectivity for $\mathrm{OX}_{2}$. It is also interesting to note that the maximum response of Nag 26 is nearly the same as that of orexin-A; the conclusion can be drawn from the phospholipase $\mathrm{C}$ assay which is not assumed to be significantly blunted (Turku et al., 2016). Thus, Nag 26 is a nearly full agonist for the $G_{q}$ response via both orexin receptors, unlike any previously described non-peptide ligand.

It might be expected that a gene promoter activity reporter assay - such as our apparently third $\mathrm{G}_{\mathrm{q}}$-dependent response, Elk-1-dependent firefly luciferase expression would be easily saturated, as there could be several limiting steps in the cascade. However, that does not seem to be the case, at least for orexin receptors in $\mathrm{CHO}$ cells; in contrast, the Elk-1 response shows a wide dynamic range (Jäntti et al., 2013; current study). For Nag 26, the Elk-1 response is perplexing, as it seems to decrease again at high Nag 26 concentrations, at least for $\mathrm{OX}_{2}$. One possibility is that this response is orexin receptor-independent and possibly reflects the loss of viability at high Nag 26 concentrations. However, it is also possible that Nag 26, at high concentrations, activates another signal transduction pathway that either directly or indirectly, i.e. by reducing the receptor response towards Elk-1 or the receptor number, counteracts the Elk-1 response. The time the receptors are stimulated by the agonists is much higher in the Elk-1 assay (5 h) than in the $\mathrm{Ca}^{2+}(2 \mathrm{~min})$, phospholipase $\mathrm{C}$ (30 min) or adenylyl cyclase (10 $\mathrm{min}$ ) assays, and thus there is time for slower processes to act as well. As this is not seen with orexin-A, this would imply that the Elk-1 response to Nag 26 displays biased agonism with respect to orexin-A. We did not investigate this further, as this takes place around the limit of Nag 26 solubility, and thus is difficult to assess and also of little interest. However, we simulated the first alternative, i.e. that Elk-1 response is determined by an orexin receptor-dependent stimulation and orexin receptor-independent 
inhibition, and that even the $\mathrm{OX}_{1}$ response is blunted by this. We thus additionally fitted the Nag 26 data for Elk-1 assuming the same non-specific response-decreasing component at high Nag 26 concentration for both receptors (Eq. 2). The results are presented in Fig. 7 and Table S1. The data can be very well described by such an equation; even the measured values from the additional experiments with $70 \mu \mathrm{M}$ Nag 26, which are not used for the fitting, make a very good match (Fig. 7). The curve-fitting values obtained for $\mathrm{OX}_{1}$ are much better in line with the results from $\mathrm{Ca}^{2+}$ and phospholipase $\mathrm{C}$ assays (Fig. 6C; Table S1). It seems possible that even the phospholipase $\mathrm{C}$ responses for $\mathrm{OX}_{1}$ and $\mathrm{OX}_{2}$ are blunted in the same way around $30 \mu \mathrm{M}$ Nag 26 (see Fig. 2). However, it should be stressed that the lack of solubility of Nag 26 limits assessment of the response at even higher concentration, leaving this curvefitting model speculative.

As concerns the read-outs for $\mathrm{G}_{\mathrm{i}}$ and $\mathrm{G}_{\mathrm{s}}$ responses, it is difficult to draw firm conclusions due to weak responses to Nag 26 for the adenylyl cyclase inhibition assay $\left(G_{i}\right)$ and the weak responses to Nag 26 on both receptors and even orexin- $\mathrm{A}$ on $\mathrm{OX}_{2}$ in the adenylyl cyclase stimulation assay $\left(\mathrm{G}_{\mathrm{s}}\right)$. As we have shown before (Holmqvist et al., 2005; Kukkonen, 2016b), the potency of even orexin-A is low for the $\mathrm{G}_{\mathrm{s}}$ response in these cells, and thus the receptor reserve and amplification of the response may be rather non-existing. In addition, the possible bell-shape - as seen in the Elk-1 assay - may also be present in this response and distort the result. It is thus not possible to judge, whether the maximum response to Nag 26 indeed is much lower than that to orexin-A in $\mathrm{OX}_{1}$ cells.

The orexin receptor-specific cell death response to Nag 26 is not very prominent. However, there is some response in $\mathrm{OX}_{2}$-expressing cells, and as even the response to orexinA is very weak, it would be worthwhile to test Nag 26 and YNT-185 in those primary cancer cells and cancer cell lines in which the anti-proliferative and pro-apoptotic responses to 
orexin receptor stimulation with orexin-A/B are prominent (Rouet-Benzineb et al., 2004; Voisin et al., 2006; Voisin et al., 2011).

In conclusion, the studies indicate that Nag 26 is a potent and nearly full agonist of orexin receptors, at least for the $\mathrm{G}_{\mathrm{q}}$ response, but that its potency is yet far from the potency of orexin-A. The studies also point out at some, though not prominent, biased agonism; the strongest indication of this is for $\mathrm{OX}_{2}$, for which the difference in potency between orexin-A and Nag 26 is much lower for the Elk-1 assay than for the $\mathrm{Ca}^{2+}$ and phospholipase $\mathrm{C}$ assays. As compared to the previously reported ligand, Yan 7874 (Turku et al., 2017), Nag 26 appears to have little detrimental, orexin receptor-independent activity, though some is seen at high concentrations. 


\section{Acknowledgments}

Santeri Suokas, Marja Peltola and Jouni Oksanen (Biochemistry and Cell Biology, Department of Veterinary Biosciences, University of Helsinki) are gratefully acknowledged for technical assistance with the experiments, and Kaj-Roger Hurme (Instrument Centre of Faculty of Agriculture and Forestry, University of Helsinki) and Raija Savolainen (Institute of Biotechnology, University of Helsinki) for all help with the liquid scintillation counting and luminescence measurements, respectively. This work was supported by the European Union (FP7-HEALTH-project GLORIA [\#602919]), the Magnus Ehrnrooth Foundation, the Finnish Cultural Foundation, the Orion Research Foundation, the Liv \& Hälsa Foundation, and the Doctoral Program in Drug Research of the University of Helsinki.

\section{Conflicts of interest}

Declarations of interest: none. 


\section{References}

Ammoun, S., Holmqvist, T., Shariatmadari, R., Oonk, H.B., Detheux, M., Parmentier, M., Åkerman, K.E., Kukkonen, J.P., 2003. Distinct recognition of OX1 and OX2 receptors by orexin peptides. J. Pharmacol. Exp. Ther. 305, 507-514.

Ammoun, S., Lindholm, D., Wootz, H., Åkerman, K.E., Kukkonen, J.P., 2006. G-proteincoupled OX1 orexin/hcrtr-1 hypocretin receptors induce caspase-dependent and -independent cell death through p38 mitogen-/stress-activated protein kinase. J. Biol. Chem. 281, 834-842.

Baimel, C., Bartlett, S.E., Chiou, L.C., Lawrence, A.J., Muschamp, J.W., Patkar, O., Tung, L.W., Borgland, S.L., 2015. Orexin/hypocretin role in reward: implications for opioid and other addictions. Br. J. Pharmacol. 172, 334-348.

Chemelli, R.M., Willie, J.T., Sinton, C.M., Elmquist, J.K., Scammell, T., Lee, C., Richardson, J.A., Williams, S.C., Xiong, Y., Kisanuki, Y., Fitch, T.E., Nakazato, M., Hammer, R.E., Saper, C.B., Yanagisawa, M., 1999. Narcolepsy in orexin knockout mice: molecular genetics of sleep regulation. Cell 98, 437-451.

Gerashchenko, D., Kohls, M.D., Greco, M., Waleh, N.S., Salin-Pascual, R., Kilduff, T.S., Lappi, D.A., Shiromani, P.J., 2001. Hypocretin-2-saporin lesions of the lateral hypothalamus produce narcoleptic-like sleep behavior in the rat. J. Neurosci. 21, 7273-7283. 
Hara, J., Beuckmann, C.T., Nambu, T., Willie, J.T., Chemelli, R.M., Sinton, C.M., Sugiyama, F., Yagami, K., Goto, K., Yanagisawa, M., Sakurai, T., 2001. Genetic ablation of orexin neurons in mice results in narcolepsy, hypophagia, and obesity. Neuron 30, 345-354.

Holmqvist, T., Johansson, L., Östman, M., Ammoun, S., Åkerman, K.E., Kukkonen, J.P., 2005. OX1 orexin receptors couple to adenylyl cyclase regulation via multiple mechanisms. J. Biol. Chem. 280, 6570-6579.

Irukayama-Tomobe, Y., Ogawa, Y., Tominaga, H., Ishikawa, Y., Hosokawa, N., Ambai, S., Kawabe, Y., Uchida, S., Nakajima, R., Saitoh, T., Kanda, T., Vogt, K., Sakurai, T., Nagase, H., Yanagisawa, M., 2017. Nonpeptide orexin type-2 receptor agonist ameliorates narcolepsy-cataplexy symptoms in mouse models. Proc. Natl. Acad. Sci. U. S. A. 114, 57315736.

Jäntti, M.H., Putula, J., Somerharju, P., Frohman, M.A., Kukkonen, J.P., 2012. OX1 orexin/hypocretin receptor activation of phospholipase D. Br. J. Pharmacol. 165, 1109-1123.

Jäntti, M.H., Putula, J., Turunen, P.M., Näsman, J., Reijonen, S., Kukkonen, J.P., 2013. Autocrine endocannabinoid signaling potentiates orexin receptor signaling upon CB1 cannabinoid-OX1 orexin receptor coexpression. Mol. Pharmacol. 83, 621-632.

Kamano, H., Burk, B., Noben-Trauth, K., Klempnauer, K.H., 1995. Differential splicing of the mouse B-myb gene. Oncogene 11, 2575-2582. 
Kantor, S., Mochizuki, T., Lops, S.N., Ko, B., Clain, E., Clark, E., Yamamoto, M., Scammell, T.E., 2013. Orexin gene therapy restores the timing and maintenance of wakefulness in narcoleptic mice. Sleep 36, 1129-1138.

Kortenjann, M., Thomae, O., Shaw, P.E., 1994. Inhibition of v-raf-dependent c-fos expression and transformation by a kinase-defective mutant of the mitogen-activated protein kinase Erk2. Mol. Cell. Biol. 14, 4815-4824.

Kukkonen, J.P., 2016a. G-protein-dependency of orexin/hypocretin receptor signalling in recombinant Chinese hamster ovary cells. Biochem. Biophys. Res. Commun. 476, 379-385.

Kukkonen, J.P., 2016b. OX orexin/hypocretin receptor signal transduction in recombinant Chinese hamster ovary cells. Cell. Signal. 28, 51-60.

Kukkonen, J.P., 2013. Physiology of the orexinergic/hypocretinergic system: a revisit in 2012. Am. J. Physiol. Cell. Physiol. 301, C2-C32.

Li, S.B., Giardino, W.J., de Lecea, L., 2017. Hypocretins and Arousal. Curr Top Behav Neurosci 33, 93-104.

Lin, L., Faraco, J., Li, R., Kadotani, H., Rogers, W., Lin, X., Qiu, X., de Jong, P.J., Nishino, S., Mignot, E., 1999. The sleep disorder canine narcolepsy is caused by a mutation in the hypocretin (orexin) receptor 2 gene. Cell 98, 365-376. 
Lund, P.E., Shariatmadari, R., Uustare, A., Detheux, M., Parmentier, M., Kukkonen, J.P., Åkerman, K.E.O., 2000. The orexin OX1 receptor activates a novel Ca2+ influx pathway necessary for coupling to phospholipase C. J. Biol. Chem. 275, 30806-30812.

Mieda, M., Willie, J.T., Hara, J., Sinton, C.M., Sakurai, T., Yanagisawa, M., 2004. Orexin peptides prevent cataplexy and improve wakefulness in an orexin neuron-ablated model of narcolepsy in mice. Proc. Natl. Acad. Sci. U. S. A. 101, 4649-4654.

Nagahara, T., Saitoh, T., Kutsumura, N., Irukayama-Tomobe, Y., Ogawa, Y., Kuroda, D., Gouda, H., Kumagai, H., Fujii, H., Yanagisawa, M., Nagase, H., 2015. Design and Synthesis of Non-Peptide, Selective Orexin Receptor 2 Agonists. J. Med. Chem. 58, 7931-7937.

Nishino, S., Ripley, B., Overeem, S., Lammers, G.J., Mignot, E., 2000. Hypocretin (orexin) deficiency in human narcolepsy. Lancet 355, 39-40.

Roecker, A.J., Cox, C.D., Coleman, P.J., 2016. Orexin Receptor Antagonists: New Therapeutic Agents for the Treatment of Insomnia. J. Med. Chem. 59, 504-530.

Rouet-Benzineb, P., Rouyer-Fessard, C., Jarry, A., Avondo, V., Pouzet, C., Yanagisawa, M., Laboisse, C., Laburthe, M., Voisin, T., 2004. Orexins acting at native OX(1) receptor in colon cancer and neuroblastoma cells or at recombinant $\mathrm{OX}(1)$ receptor suppress cell growth by inducing apoptosis. J. Biol. Chem. 279, 45875-45886. 
Scammell, T.E., Arrigoni, E., Lipton, J.O., 2017. Neural Circuitry of Wakefulness and Sleep. Neuron 93, 747-765.

Thompson, M.D., Xhaard, H., Sakurai, T., Rainero, I., Kukkonen, J.P., 2014. OX1 and OX2 orexin/hypocretin receptor pharmacogenetics. Front Neurosci 8, 57.

Turku, A., Borrel, A., Leino, T.O., Karhu, L., Kukkonen, J.P., Xhaard, H., 2016.

Pharmacophore model to discover OX1 and OX2 orexin receptor ligands. J. Med. Chem. 59, $8263-8275$

Turku, A., Rinne, M.K., Boije Af Gennas, G., Xhaard, H., Lindholm, D., Kukkonen, J.P., 2017. Orexin receptor agonist Yan 7874 is a weak agonist of orexin/hypocretin receptors and shows orexin receptor-independent cytotoxicity. PLoS One 12, e0178526.

Willie, J.T., Chemelli, R.M., Sinton, C.M., Tokita, S., Williams, S.C., Kisanuki, Y.Y., Marcus, J.N., Lee, C., Elmquist, J.K., Kohlmeier, K.A., Leonard, C.S., Richardson, J.A., Hammer, R.E., Yanagisawa, M., 2003. Distinct narcolepsy syndromes in Orexin receptor-2 and Orexin null mice: molecular genetic dissection of Non-REM and REM sleep regulatory processes. Neuron 38, 715-730.

Voisin, T., El Firar, A., Fasseu, M., Rouyer-Fessard, C., Descatoire, V., Walker, F., Paradis, V., Bedossa, P., Henin, D., Lehy, T., Laburthe, M., 2011. Aberrant expression of OX1 receptors for orexins in colon cancers and liver metastases : an openable gate to apoptosis. Cancer Res. 71, 3341-3351. 
Voisin, T., Firar, A.E., Avondo, V., Laburthe, M., 2006. Orexin-induced apoptosis: the key role of the seven-transmembrane domain orexin type 2 receptor. Endocrinology 147, 49774984. 


\section{Figures}

Figure 1. Rinne et al.
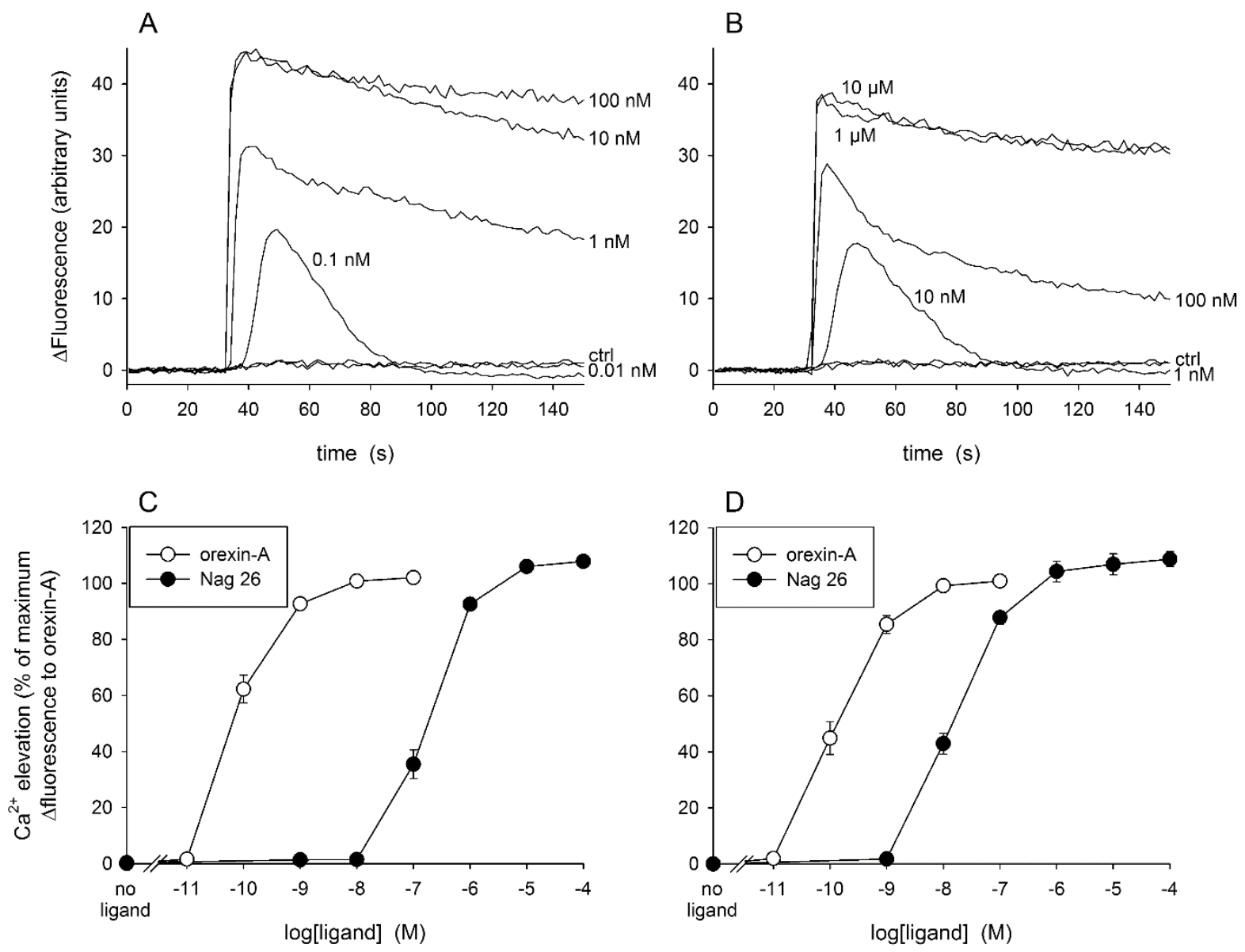

Fig. 1. $\mathrm{Ca}^{2+}$ response to orexin-A and Nag 26. (A, B) Representative fluorescence traces for orexin-A (A) and Nag 26 (B) in $\mathrm{OX}_{2}$ receptor-expressing cells. (C, D) Average responses in $\mathrm{OX}_{1}(\mathrm{C})$ and $\mathrm{OX}_{2}(\mathrm{D})$ receptor-expressing cells. $n=6-7$. 
Figure 2. Rinne et al.
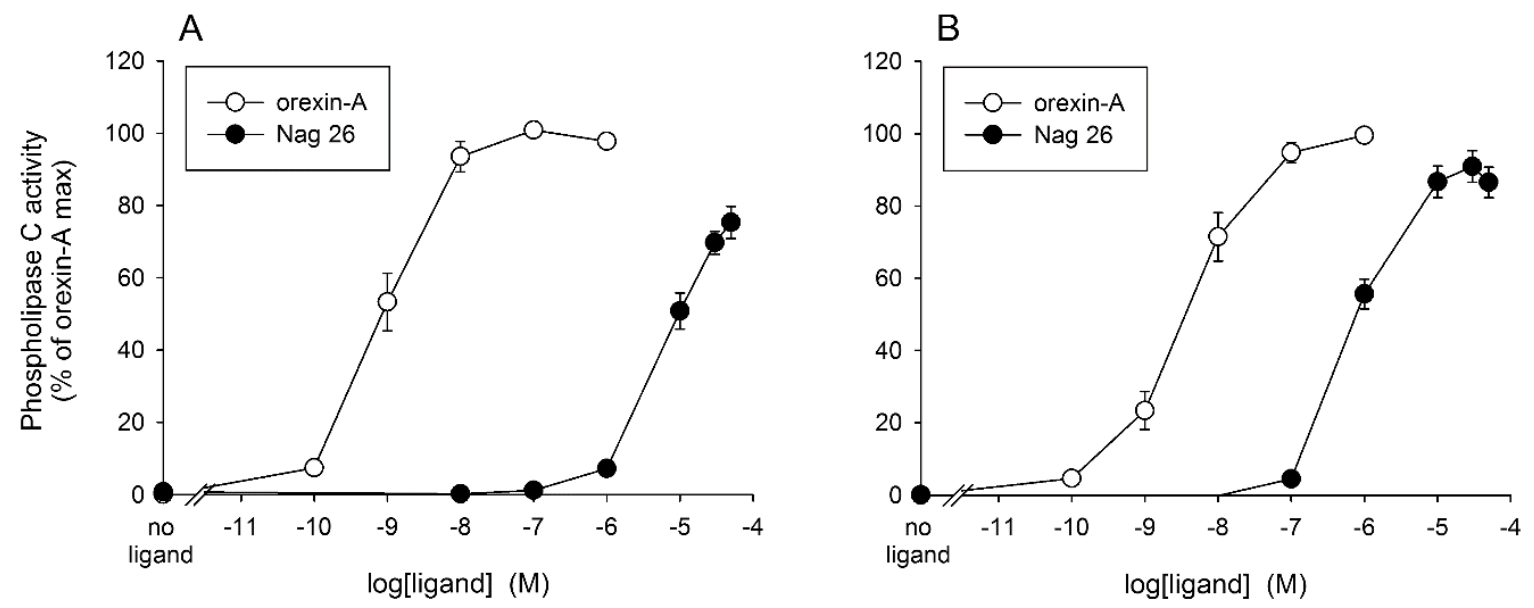

Fig. 2. Phospholipase $\mathrm{C}$ response to orexin- $\mathrm{A}$ and $\mathrm{Nag} 26$ in $\mathrm{OX}_{1}(\mathrm{~A})$ and $\mathrm{OX}_{2}(\mathrm{~B})$ receptorexpressing cells. $n=5$.

Figure 3. Rinne et al.

A

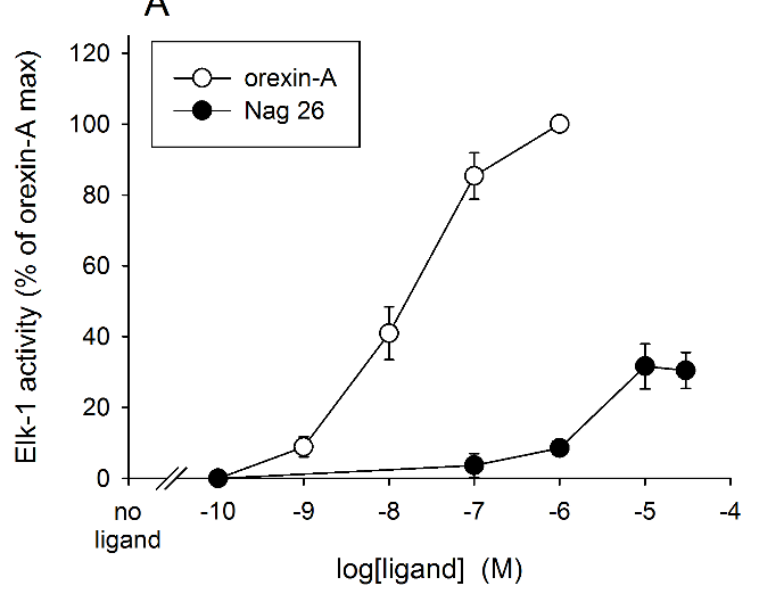

B

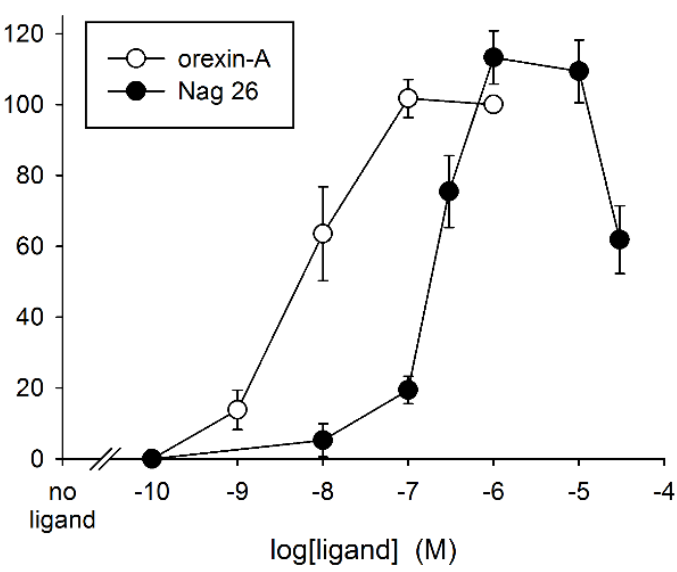

Fig. 3. Elk-1 driven luciferase activity in response to orexin- $\mathrm{A}$ and $\mathrm{Nag} 26$ in $\mathrm{OX}_{1}(\mathrm{~A})$ and $\mathrm{OX}_{2}$ (B) receptor-expressing cells. $n=5$. 
Figure 4. Rinne et al.
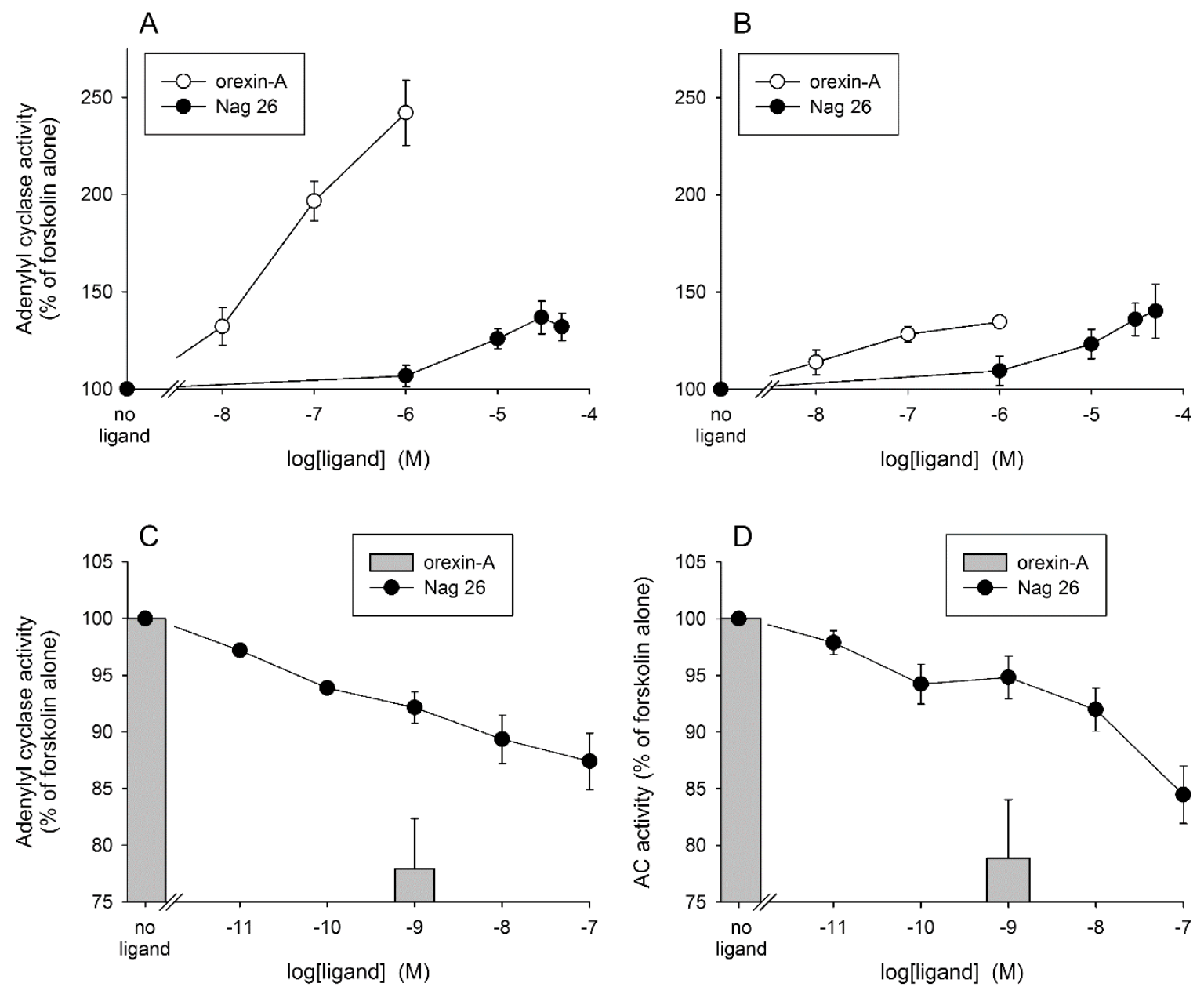

Fig. 4. Adenylyl cyclase response to orexin-A and Nag 26. In the left hand column (A, C)

$\mathrm{OX}_{1}$ and in the right hand column $(\mathrm{B}, \mathrm{D}) \mathrm{OX}_{2}$. In the upper row $(\mathrm{A}, \mathrm{B})$ pertussis toxin-treated cells and in the lower row (C, D) cholera toxin-treated cells. $n=4-5$. 
Figure 5. Rinne et al.
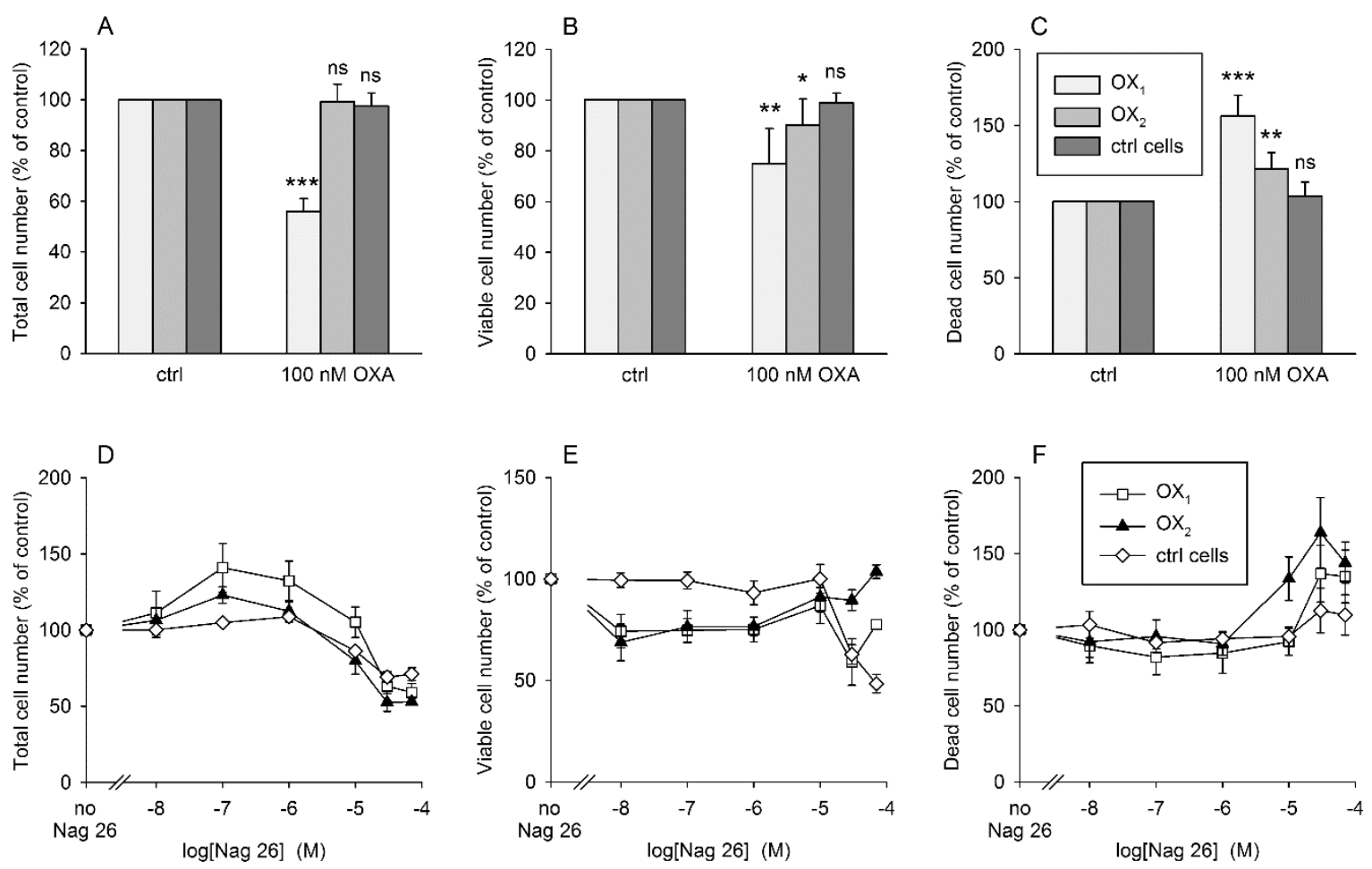

Fig. 5. Cell viability and death upon orexin- $\mathrm{A}$ and Nag 26 challenge of $\mathrm{OX}_{1}$ and $\mathrm{OX}_{2}$ receptor-expressing and wild-type (ctrl) cells. (A, D) Total cell numbers were assessed by the Hoechst fluorescence, (B, E) viable cell numbers by the PrestoBlue fluorescence divided by the Hoechst fluorescence, and $(\mathrm{C}, \mathrm{F})$ necrotic cell numbers by the YoPro fluorescence divided by the Hoechst fluorescence. All the results are normalized to the corresponding control (each cell type stimulated with vehicle only). $n=5-7$. 
Figure 6. Rinne et al.
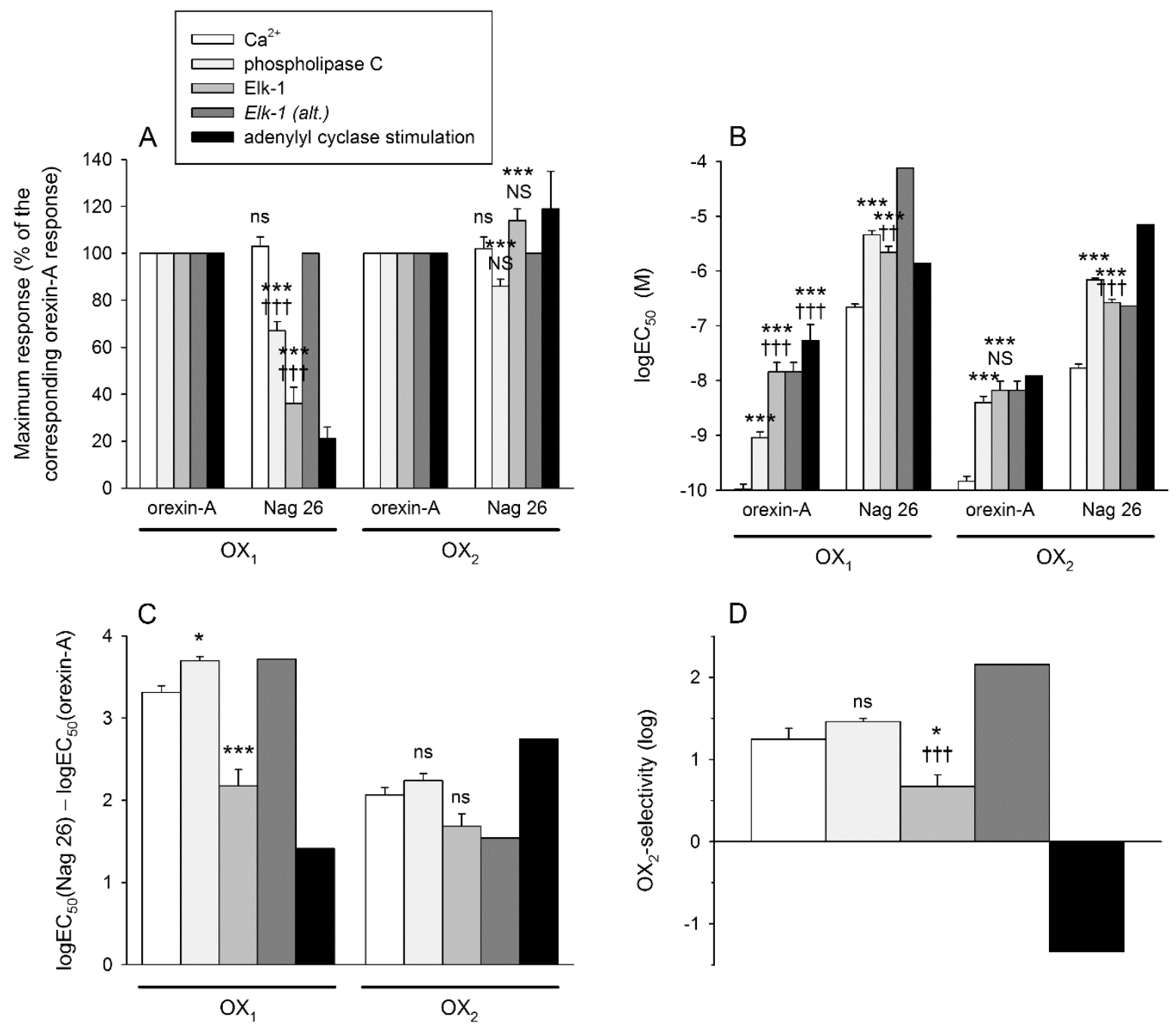

Fig. 6. Summary of the curve-fitting analyses of the concentration-response data for the different assays (also presented in Table S1). No error bars are seen for the data which was normalized to $100 \%$ (orexin- $\mathrm{A}$ in $\mathrm{A}$ ) or for which the curve fitting was performed with averaged data (A-D; see Table S1). (A) The maximum responses to the ligands. The responses were normalized to the orexin-A response separately for each receptor subtype. The first comparison (Nag 26) is to the corresponding orexin-A response and the second comparison of the Nag 26 phospholipase $\mathrm{C}$ and Elk-1 responses to the $\mathrm{Nag} 26 \mathrm{Ca}^{2+}$ response. (B-D) Comparison of the ligand potencies. (B) Potencies as such. The first comparison is for 
each receptor subtype and ligand to the corresponding $\mathrm{Ca}^{2+}$ response and the second comparison to the corresponding phospholipase $\mathrm{C}$ response. (C) The potencies of Nag 26 in relation to the potencies of orexin-A. The comparison is to the $\mathrm{Ca}^{2+}$ response separately for each receptor subtype. (D) The potency-based selectivity of Nag 26 for $\mathrm{OX}_{2}$ receptors. The $\log \mathrm{EC}_{50}(\mathrm{Nag} 26)-\log \mathrm{EC}_{50}($ orexin-A) values were calculated in each batch of the cells (as in C) and then the value for $\mathrm{OX}_{2}$ was subtracted from the value for $\mathrm{OX}_{1}$. The values were then averaged for this subgraph. The first comparison is to the $\mathrm{Ca}^{2+}$ response and the second to the phospholipase C response. $n=4-7$ (indicated in Table S1).

\section{Figure 7. Rinne et al.}

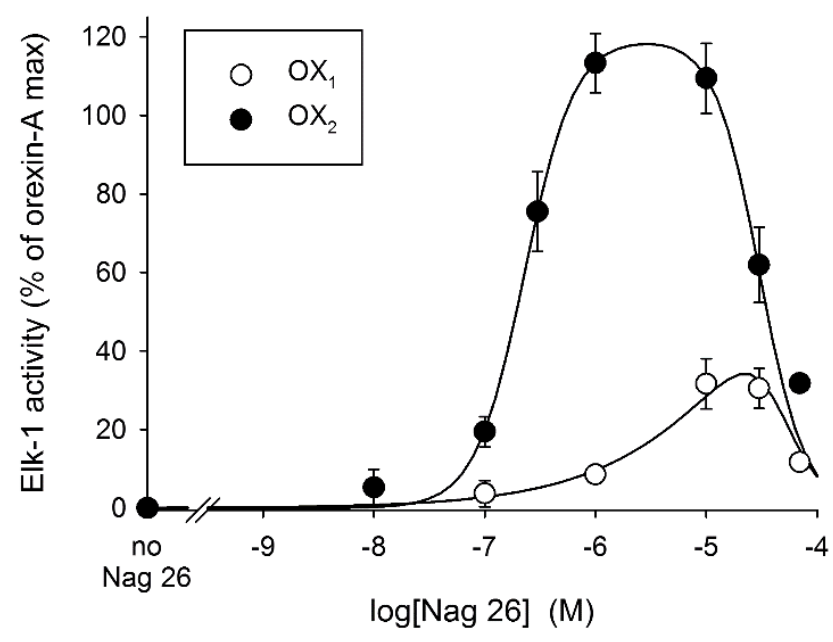

Fig. 7. Curve-fitting of all the Nag 26 responses according to Eq. 2. Both curves were fitted at the same time and the values of response ${ }_{\max }, \mathrm{K}_{\mathrm{i}}$, and $\mathrm{n}_{\mathrm{h} 2}$ were kept equal for $\mathrm{OX}_{1}$ and $\mathrm{OX}_{2}$. These fitted values are response $\mathrm{max}_{\max }\left(\mathrm{OX}_{1}\right)=$ response $_{\max \left(\mathrm{OX}_{2}\right)}=120 \%, \mathrm{~K}_{\mathrm{i}^{\prime}\left(\mathrm{OX}_{1}\right)}=\mathrm{K}_{\mathrm{i}^{\prime}\left(\mathrm{OX}_{2}\right)}=$ $30.4 \mu \mathrm{M}$, and $\mathrm{n}_{\mathrm{h} 2\left(\mathrm{Ox}_{1}\right)}=\mathrm{n}_{\mathrm{h} 2\left(\mathrm{OX}_{2}\right)}=2.16$, and the other values are $\mathrm{EC}_{50\left(\mathrm{Ox}_{1}\right)}=75400 \mu \mathrm{M}$, 
$\mathrm{EC}_{50\left(\mathrm{OX}_{2}\right)}=230 \mu \mathrm{M}, \mathrm{n}_{\mathrm{h} 1\left(\mathrm{Ox}_{1}\right)}=0.56$, and $\mathrm{n}_{\mathrm{h} 1\left(\mathrm{OX}_{2}\right)}=1.96 . n=5$, except for $70 \mu \mathrm{M}$ Nag 26 which represent only single determinations and have not been used for the curve-fitting. 
Supplementary data for

Pharmacological characterization of the orexin/hypocretin receptor agonist Nag 26

Maiju K. Rinne, Teppo O. Leino, Ainoleena Turku, Pauli M. Turunen, Yana Steynen, Henri

Xhaard, Erik A. A. Wallén and Jyrki P. Kukkonen 
EJP: Supplementary data for Rinne et al.

Pharmacological characterization of the orexin/hypocretin receptor agonist Nag 26

Table S1. Summary of the curve-fitting analyses of the concentration-response data for the different assays (also presented in Fig. 6).

\begin{tabular}{|c|c|c|c|c|c|c|c|}
\hline & & & $\mathrm{Ca}^{2+}$ & Phospholipase C & Elk-1 & Elk-1 (alt. $)^{a}$ & $\begin{array}{l}\text { Adenylyl cyclase } \\
\text { stimulation }\end{array}$ \\
\hline \multirow[t]{7}{*}{$\mathrm{OX}_{1}$} & orexin-A & Max & 100 & 100 & 100 & 100 & 100 \\
\hline & & $\mathrm{n}_{\mathrm{h}}$ & $1.68 \pm 0.18$ & $1.24 \pm 0.09$ & $1.01 \pm 0.18$ & 1.01 & $1^{b}$ \\
\hline & & $n$ & 7 & 5 & 5 & & 6 \\
\hline & & $\log \mathrm{EC}_{50}$ & $-6.66 \pm 0.06$ & $-5.34 \pm 0.077$ & $-5.66 \pm 0.11$ & -4.12 & -5.86 \\
\hline & & fold difference & $2050 \pm 390$ & $4960 \pm 580$ & $149 \pm 69$ & 5220 & 26 \\
\hline & & $\mathrm{n}_{\mathrm{h}}$ & $1.23 \pm 0.05$ & $1.44 \pm 0.08$ & $1.26 \pm 0.17$ & 0.56 & $1^{b}$ \\
\hline & & $n$ & 7 & 5 & 5 & & 5 \\
\hline \multirow{6}{*}{$\overline{\mathrm{OX}_{2}}$} & & $n$ & 7 & 5 & 5 & & 6 \\
\hline & Nag 26 & Max & $102 \pm 5$ & $86 \pm 3$ & $114 \pm 5$ & 120 & $119 \pm 16$ \\
\hline & & $\log \mathrm{EC}_{50}$ & $-7.77 \pm 0.07$ & $-6.16 \pm 0.03$ & $-6.58 \pm 0.06$ & -6.64 & -5.16 \\
\hline & & fold difference & $116 \pm 24$ & $172 \pm 35$ & $48.3 \pm 16.9$ & 35 & 558 \\
\hline & & $\mathrm{n}_{\mathrm{h}}$ & $1.07 \pm 0.09$ & $1.64 \pm 0.08$ & $2.07 \pm 0.25$ & 1.96 & $1^{b}$ \\
\hline & & $n$ & 7 & 5 & 4 & & 6 \\
\hline
\end{tabular}


"Max" refers to the maximum response; the maximum responses were normalized to the maximum response to orexin-A (100\%) in each batch of cells before averaging. "Fold difference" is given for the $\mathrm{EC}_{50}(\mathrm{Nag} 26)$ as compared the $\mathrm{EC}_{50}$ (orexin-A). The value was separately calculated in each batch of cells before averaging, except for the values marked with ${ }^{\text {a }}$, as the low responses made the determinations in separate experiments uncertain, and thus the average was fitted for these instead.

${ }^{a}$ The averaged data were alternatively fitted assuming the same inhibitory component for both receptor subtypes. See 2.8 . Data analysis and Fig. 7 for details.

${ }^{b}$ The response was fixed to $\mathrm{n}_{\mathrm{h}}=1$ due to low magnitude, and even the higher response for orexin- $\mathrm{A}$ in $\mathrm{OX}_{1}$-expressing cells was treated in the same way for the sake of consequence.

${ }^{c}$ Please observe that the response does not fully saturate within the concentration range usable and thus the estimate is somewhat uncertain. 
EJP: Supplementary material for Rinne et al.,

Pharmacological characterization of the orexin/hypocretin receptor agonist Nag 26
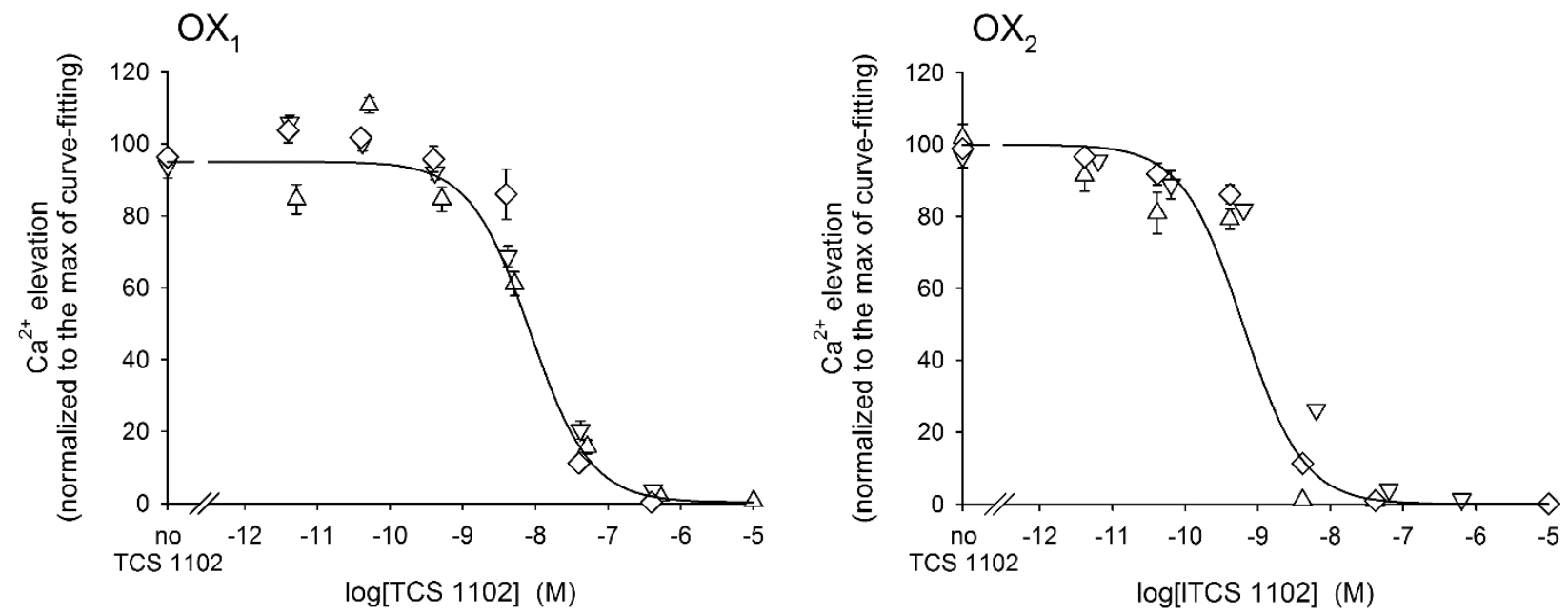

Fig. S1. The concentration-dependent inhibition by TCS 1102 of the $\mathrm{Ca}^{2+}$ response to Nag 26 (fixed concentration. Nag 26 concentration was chosen to be close to the $\mathrm{EC}_{50}$ value of $\mathrm{Nag} 26$ in each experiment ( $n=3$; different symbols); the concentrations used were 100-300 nM for $\mathrm{OX}_{1}$ and 10$20 \mathrm{nM}$ for $\mathrm{OX}_{2}$. The TCS 1102 concentrations in the figures have been adjusted for the agonist concentrations and $\mathrm{EC}_{50}$ values, and thus directly indicate the apparent TCS 1102 binding and $\mathrm{K}_{\mathrm{i}}$. 
EJP: Supplementary material for Rinne et al.,

Pharmacological characterization of the orexin/hypocretin receptor agonist Nag 26

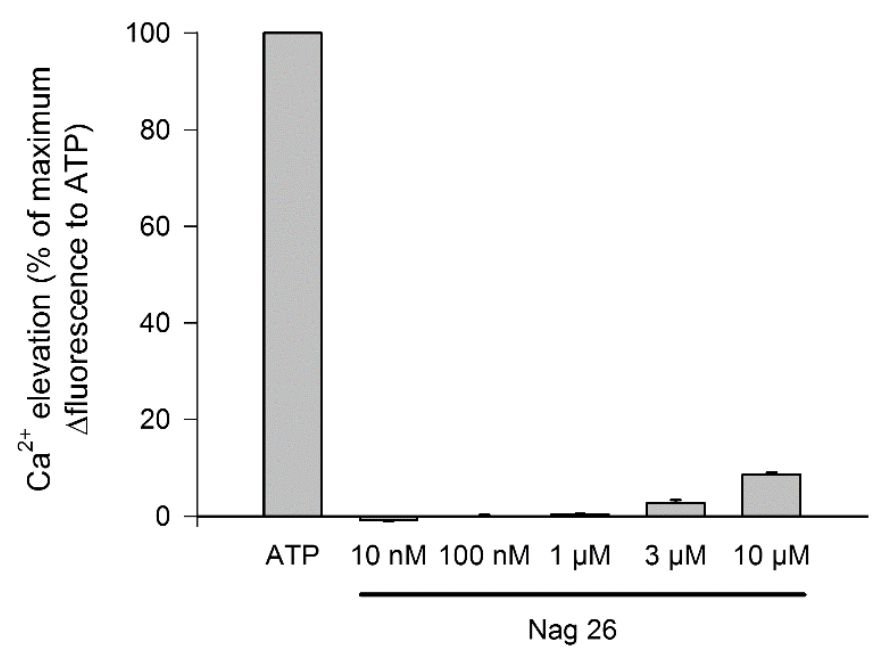

Fig. S2. Nag 26-mediated $\mathrm{Ca}^{2+}$ elevations in ctrl CHO cells. $n=3$. As a positive control $100 \mu \mathrm{M}$ ATP is used. Please note that $100 \mu \mathrm{M}$ ATP gives a $\mathrm{Ca}^{2+}$ response which is of approximately same magnitude as the maximum response to orexin-A in orexin receptor-expressing cells (Turku et al., 2017), and thus the Nag 26 responses in these cells can be directly compared to the Nag 26 responses in orexin receptor-expressing cells (Fig. 1). 
EJP: Supplementary material for Rinne et al.,

Pharmacological characterization of the orexin/hypocretin receptor agonist Nag 26

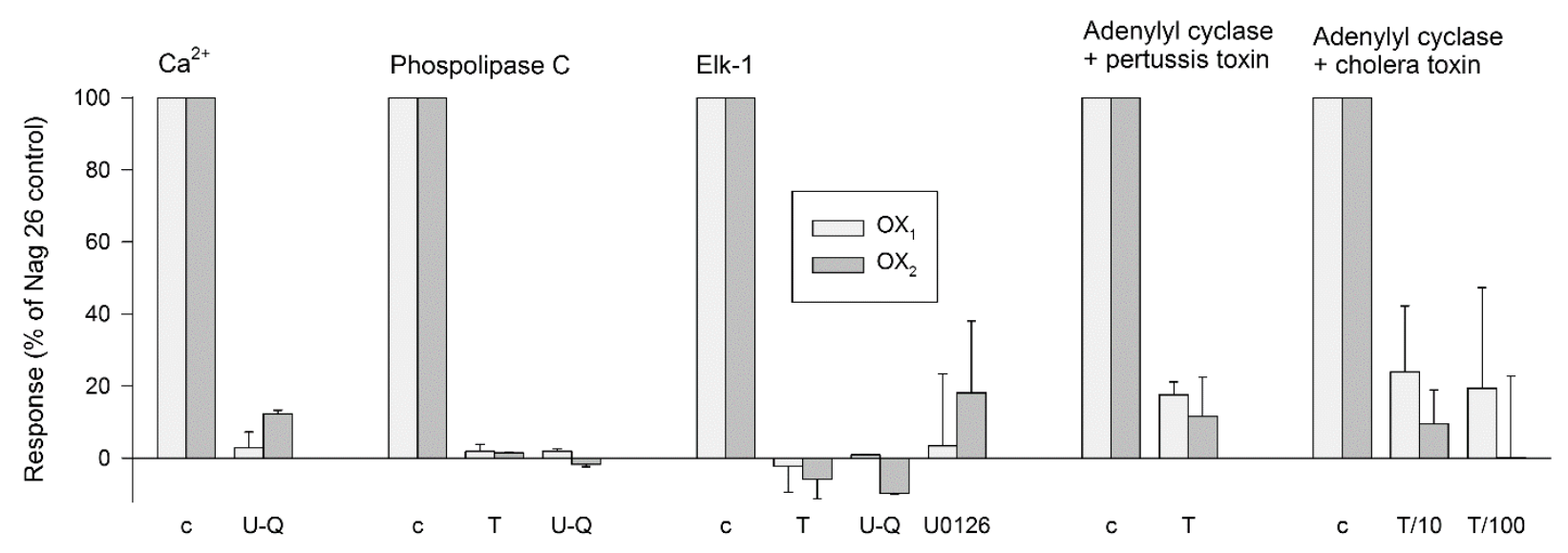

Fig. S3. The sensitivity of the Nag 26-mediated responses to inhibitors. The abbreviations are as follows: c, control (vehicle); T, 10-30 $\mu \mathrm{M}$ TCS; T/10, $10 \mu \mathrm{M}$ TCS and $10 \mathrm{nM} \mathrm{Nag} \mathrm{26;} \mathrm{T/100,} 30$

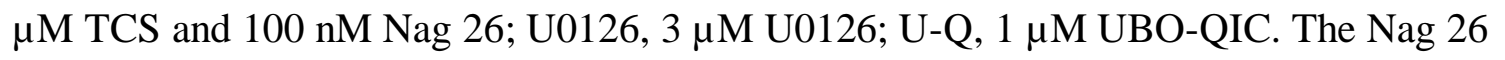
concentrations used are $10 \mu \mathrm{M}$ for $\mathrm{Ca}^{2+}, 30 \mu \mathrm{M}$ for phospholipase $\mathrm{C}, 30 \mu \mathrm{M} / 1 \mu \mathrm{M}$ for Elk-1 (OX and $\mathrm{OX}_{2}$, respectively), $30 \mu \mathrm{M}$ for adenylyl cyclase + pertussis toxin, and 10 or $100 \mathrm{nM}$ for adenylyl cyclase + cholera toxin (as indicated above), and. $n=3-5$. 
EJP: Supplementary material for Rinne et al.,

Pharmacological characterization of the orexin/hypocretin receptor agonist Nag 26

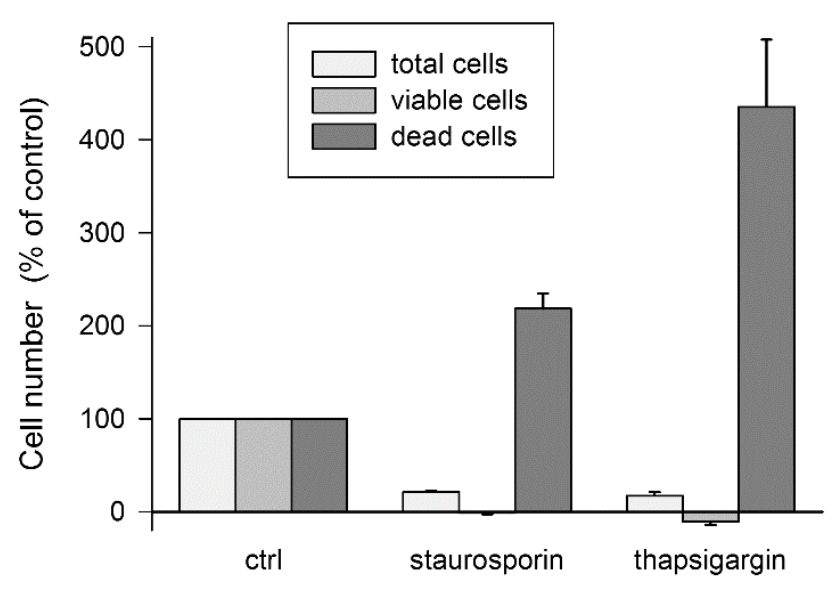

Fig. S4. The impact of the positive controls for reduced cell proliferation and viability, and increased cell death, $300 \mathrm{nM}$ staurosporin and $300 \mathrm{nM}$ thapsigargin. The parameters are the same as in Fig. 5. $n=4-6$.

\section{References}

Turku A, Rinne MK, Boije Af Gennas G, Xhaard H, Lindholm D, Kukkonen JP (2017). Orexin receptor agonist Yan 7874 is a weak agonist of orexin/hypocretin receptors and shows orexin receptor-independent cytotoxicity. PLoS One 12: e0178526. 